\title{
HILGARDIA
}

A Journal of Agricultural Science Published by the California Agricultural Experiment Station

\section{ENTOMOPHTHOROUS FUNGI PARASITIC ON THE SPOTTED ALFALFA APHID}

IRVIN M. HALL and PAUL H. DUNN 
Five species of entomophthorous fungi have been isolated from spotted alfalfa aphids collected in California. Of these, the two that appear most effective in the biological control of the aphid in California have also been found in India, Iraq, and Israel. One species has previously been described as Entomophthora coronata. The following names are proposed for the four new species described herein:

Entomopbibora obscura

Entomopbtbora ignobilis

Entomopbtbora exitialis

Entomopbtbora virulenta 


\section{H I L G A R D I A}

A Journal of Agricultural Science Published by

the California Agricultural Experiment Station

VOL. 27

SEPTEMBER, 1957

No. 4

\section{ENTOMOPHTHOROUS FUNGI PARASITIC ON THE SPOTTED ALFALFA APHID ${ }^{1}$}

IRVIN M. HALL ${ }^{2}$ and PAUL H. DUNN ${ }^{3}$

\section{INTRODUCTION}

SHortLy AFTER the spotted alfalfa aphid, Therioaphis maculata (Buckton), appeared in California and began its rapid and serious spread throughout the alfalfa-growing areas of the state, a search was started to determine what role, if any, pathogenic microörganisms were playing in the biological control of the pest. Aiding in the search for pathogens of the spotted alfalfa aphid were representatives of the University of California and the U. S. Department of Agriculture, who were exploring the United States, Europe, the Middle East, India, and North Africa for parasites, predators, and other natural enemies of the aphid. Simultaneously a survey program covering the infested areas of southern California was undertaken. Since the most important known microörganisms pathogenic to aphids are phycomycete fungi belonging to the order Entomophthorales, it was hoped that at least one species of entomogenous fungi could be found for possible use in combatting the spotted alfalfa aphid.

The results of this search for pathogens were unusually successful, and the spotted alfalfa aphid in California has been found to be susceptible to infection by five different species of entomophthorous fungi (Hall and Dietrick, 1955; Hall and Dunn, 1957). Two of these fungi have been isolated or observed from specimens of the aphid collected in India, Iraq, and Israel, indicating that they are contributing to the control of the spotted alfalfa aphid in its native home.

The following is a report on a taxonomic study of the species of entomophthorous fungi isolated from specimens of Therioaphis maculata.

\footnotetext{
${ }^{1}$ Received for publication March 26, 1957.

${ }^{2}$ Assistant Insect Pathologist in Biological Control, Citrus Experiment Station, Riverside.

${ }^{3}$ Senior Laboratory Technician in Biological Control, Citrus Experiment Station, Riverside.
} 


\section{SYNONYMY}

It is recognized that there is serious confusion among past and present workers with this group concerning the proper usage of the generic names Empusa and Entomophthora, since the validity of the name Empusa erected by Cohn (1855) has been challenged by some writers because of its previous application to a genus of orchids. Despite the invalidity of the name Empusa, which must be rejected according to the homonym rule of section 12 , International Rules of Botanical Nomenclature, some modern workers (Fitzpatrick, 1930; MacLeod, 1956) have continued to follow the one genus grouping employed by Thaxter (1888), who concluded that the name Empusa has priority and sufficient weight of authority to make its use good, and that the orchidaceous genus Empusa is now a synomym and unlikely to cause confusion. Steinhaus (1949) speculates on the probability that with further detailed studies two valid genera will be recognized; but since no final official ruling has been made on this nomenclatorial problem, the writers tend to agree with Kevorkian (1937) who subscribes to a strict interpretation of the homonym rule and the use of the generic name Entomophthora rather than Empusa.

\section{DISTRIBUTION}

Although there are no published reports of fungus diseases of the spotted alfalfa aphid or other closely related species, other than the previously mentioned papers of Hall and Dietrick (1955) and Hall and Dunn (1957), a thorough search of the literature has established that 10 described species of entomophthorous fungi are reported to attack various species of aphids in many parts of the world. The species of the genus Entomophthora described from, or otherwise observed on, aphids are as follows: E. aphidis Hoffman, 1858 (see Fresenius, 1858), on aphids of many genera throughout the world; $E$. atrosperma Petch, 1932, on an unidentified aphid in Great Britain; E. chromaphidis Burger and Swain, 1918, on the walnut aphid Chromaphis juglandicola (Kaltenbach) in California; E. coronata (Costantin), 1897, Kevorkian, 1937, on several species of aphids in the United States and Europe; $E$. fresenii (Nowakowski), 1883, on many aphids in the United States and Europe; E. lageniformis (Thaxter), 1888, on aphids on gray birch, Betula populifolia Marsh, in the United States; $E$. occidentalis (Thaxter), 1888, on aphids on gray birch in the United States and on the plane tree, Platanus sp., in Great Britain; E. planchoniana Cornu, 1873, Petch non Thaxter, 1937, on aphids on raspberry, Rubus sp., in the United States and Europe; E. sphaerosperma Fresenius, 1856, on a number of species of aphids throughout the world; and $E$. thaxteriana (Petch), 1937, on several genera of aphids in the United States and Europe.

${ }^{4}$ International Rules of Botanical Nomenclature. Third Edition. "Section 12, Rejection of names. c. A name of a taxon is illegitimate and must be rejected if it is a later homonym, that is if it duplicates a name previously and validly published for a taxon of the same rank based on a different type. Even if the earlier homonym is illegitimate, or is generally treated as a synonym on taxonomic grounds, the later homonym must be rejected." 


\section{ENTOMOPHTHOROUS FUNGI IN CALIFORNIA}

The first fungus observed in this study was found in a single dead spotted alfalfa aphid collected near Lakeview, Riverside County, in December, 1954 (Hall and Dietrick, 1955). The host specimen was normal in appearance except for its dark-brown color and the presence of a number of small, shiny, colorless spheres which appeared to be attached to the tips of the dorsal spines. Microscopic examination revealed that the spheres were conidial spores and that the body of the dead host was filled with hyphal bodies of an entomophthorous fungus. Transfers of portions of the host to sterilized potato resulted in the isolation of the fungus, which has since been cultivated on a variety of artificial media.

In March of 1955, the receipt of a small number of dead spotted alfalfa aphids collected at Meloland in Imperial County resulted in the isolation of a second entomophthorous fungus of apparent low virulence. Where present, neither this fungus nor the one previously isolated controlled the aphid during periods of favorable weather, and only 1 to 5 per cent of the aphids were infected by either of these organisms in the fields.

The occurrence of fungus epizootics in economic populations of spotted alfalfa aphids in widespread areas of southern California in the fall of 1955 added impetus to the program and prompted more investigation, resulting in the isolation of two highly pathogenic entomophthorous fungi. One fungus with distinctive ovoid conidia was first isolated from specimens collected near Del Mar, San Diego County, in September, 1955, and was later observed killing aphids in many parts of southern California. Its subsequent spread to other parts of the state by natural and artificial means (Hall and Dunn, 1957 ) and its success as a control agent in many of these areas indicates that it is the most effective fungus attacking the spotted alfalfa aphid in California. Another fungus, with spherical conidia, was isolated from aphids collected near Riverside in October, 1955, and it too was subsequently collected from many different fields in southern California, including some where the Del Mar fungus was present. Although the natural spread of this Riverside isolate has been limited, it is extremely pathogenic and capable of causing high mortality to aphid populations.

A further attempt in March, 1956, to culture fungi from dead spotted alfalfa aphids collected in the Del Mar area resulted in the isolation of a fifth distinct fungus (figs. 1-3) which differs considerably from the earlier isolates. Study of the stages of its life cycle revealed that this organism forms basally papillate spherical conidia, averaging $36 \mu$ in diameter, on unbranched conidiophores, and at times, in old cultures, forms conidia-like resting spores covered with hairlike projections. This fungus is quite similar to the species described by Martin (1925) as Conidiobolus villosus, a saprophyte on decayed wood in Iowa. Except for a small discrepancy in the average diameter of the conidia, marked similarities have led the writers to believe that it is the same species as the one reported from the green peach aphid in Maine by Harris (1948) to be Entomophthora coronata (Cost.) Kevorkian, although the microconidia described in detail by Kevorkian (1937) in his study of the species have not been observed. 
The four remaining fungi isolated from the spotted alfalfa aphid have been cultivated on standard mycological media, and a study has been made of the stages in the life cycle of each organism. Noticeable morphological and cultural variations give evidence that they are distinct species. A comparison of their characteristics with those of previously described entomophthorous fungi from aphids as well as other insects indicates that they are distinctly different from all previously described species of the genus Entomophthora (Empusa) and that they should be considered as new species.

\section{Entomophthora obscura, n.sp.}

(Figs. 4, 5)

Conidia globosa, basi papillato, cytoplasmate pergranoso, pauca tantum in superficie hospitis efformata; longitudo (basi haud excepto) 36-52 $\mu$, med. $45 \mu$; latitudo 32-44 $\mu$, med. $40 \mu$. Conidia secundaria primariis similia, sed minora. Conidiophori non ramosi, pauci tantum per hospitis integumentum producti, nullo tegumento super hospitis corpus formato. Corpora hyphalia segmenta hypharum, apicibus rotundis, nonnumquam curvata vel torta, aliquando ramosa 15-23 $\mu$ in diam., 50-200 $\mu$ longa. Cystidia hospiti desunt. Sporae perdurantes azygosporae (paucae zygosporae inventae); pleraeque globosae, cytoplasma densum atque granosum, saepe unum vel plures vacuoles (vel olei globulos) continens habentes, episporio leni atque 3-6 $\mu$ crasso, hae sunt 35-55 $\mu$ in diam. ; aliae, haud raro in mediis artificialibus (i.e., Solano tuberoso L. sterilizato) inventae, sunt chlamydosporae forma inaequabiles $61-105 \times 112-122 \mu$ atque forma perinaequabiles sporae interstitiales, cytoplasmate granoso vacuolis (vel olei globulis) magnis (usque ad $30 \mu$ in diam.) pleno, 24-31 $\times 44-82 \mu$. Hospes substrato fixus probosci; nulla rhizoidea inventa.

Hospes: Hemiptera, Aphidae. Therioaphis maculata (Buckton) in Medicagine sativa L.

Conidia spherical, with papillate base; cytoplasm quite granular; only a few formed on surface of host; length (including base) 36-52 $\mu$, average $45 \mu$; width $32-44 \mu$, average $40 \mu$. Secondary conidia like the primary but smaller. Conidiophores unbranched; only a few extend through the host integument; no covering formed over the host body. Hyphal bodies sections of hyphae with rounded ends, sometimes curved or twisted, occasionally branched ; 15$23 \mu$ thick, 50-200 $\mu$ long. Cystidia absent on the host. Resting spores azygospores (few zygospores); spherical forms which predominate have dense granular cytoplasm, often with one to several large vacuoles or oil globules, epispore smooth, 3-6 $\mu$ thick, 35-55 $\mu$ in diameter; other forms common on artificial media (sterilized potato) are irregular chlamydospores measuring 61-105 $\times 112-122 \mu$ and very irregular interstitial spores with granular cytoplasm filled with large vacuoles or oil globules (up to $30 \mu$ in diameter) and measuring 24-31 $\times 44-82 \mu$. Host attached to substratum by proboscis; no rhizoids noted.

Host: Hemiptera, Aphidae. Therioaphis maculata (Buckton) on alfalfa, Medicago sativa $\mathrm{L}$.

Habitat: U. S. A.: California (Lakeview, Riverside County). 
This fungus is similar in some respects to Entomophthora thaxteriana Petch, differing mainly in the size of the conidia (larger than those of $E$. thaxteriana) and the shape of the hyphal bodies ( $E$. obscura hyphal bodies are short-to-elongate sections of hyphae, often branched, curved, or twisted, while those of $E$. thaxteriana are spherical).

\section{Entomophthora ignobilis, n.sp.}

(Figs. 6, 7)

Conidia paene globosa, basi papillato, cytoplasmate granoso atque denso; longitudo (basi haud excepto) 26-43 $\mu$, med. $39 \mu$; latitudo 21-34 $\mu$, med. $31 \mu$. Conidia secundaria primariis similia. Conidiophori non ramosi, pauci tantum per hospitis integumentum producti, nullo tegumento super hospitis corpus formato. Corpora hyphalia brevia hypharum segmenta, apicibus rotundis, saepe ramosa vel torta ; 10-15 $\mu$ lata; 50-60 $\mu$ (vel plura) longa. Cystidia hospiti desunt. Sporae perdurantes zygosporae (paucae azygosporae) globosae, ex apicibus aut e lateribus corporum hyphalium crescentes; episporio leni atque crasso ; $23-50 \mu$ in diam., med. $35 \mu$. Hospes substrato fixus probosci; nulla rhizoidea inventa.

Hospes: Hemiptera, Aphidae. Therioaphis maculata (Buckton) in Medicagine sativa L.

Conidia almost spherical, with papillate base, cytoplasm granular, dense; length (including base) 26-43 $\mu$, average $39 \mu$; width $21-34 \mu$, average $31 \mu$. Secondary conidia like the primary. Conidiophores unbranched; only a few extend through the host integument; no covering is formed over the host body. Hyphal bodies short sections of hyphae with rounded ends, often branched or twisted ; 10-15 $\mu$ thick, 50-60 $\mu$ (or more) long. Cystidia absent on the host. Resting spores zygospores (few azygospores), spherical, formed terminally or laterally from hyphal bodies; epispore smooth, thick; diameter $23-50 \mu$, average $35 \mu$. Host attached to substratum by proboscis; no rhizoids noted.

Host: Hemiptera, Aphidae. Therioaphis maculata (Buckton) on alfalfa, Medicago sativa L.

Habitat: U. S. A.: California (Meloland, Imperial County)

This fungus is quite similar to $E$. obscura in some of its morphological characteristics, but it differs considerably in others and is notably different in certain cultural aspects. Entomophthora ignobilis produces spherical zygospores on a variety of artificial media, while $E$. obscura forms spherical azygospores as well as irregularly shaped interstitial azygospores on some media and only large irregular chlamydospores on sterilized potato.

\section{Entomophtbora Exitialis, n.sp.}

(Figs. 8-11)

Conidia ovoidea, apicibus rotundis, aliquando pyriformia vel forma inaequabilia ; uninucleata; 17-23 $\mu$ longa (med. $20 \mu$ ) ; 9-12 $\mu$ lata (med. $11 \mu$ ). Conidia secundaria primariis similia, sed paulo minora, quodque formatum ad apicem brevis germinationis tubuli, qui aut ex apice aut e latere conidii primarii crescit. Conidiophori ramosi, breves, in tegumentum russeum super totum hospitis corpus coalescentes. Corpora hyphalia segmenta hypharum 
brevia atque gracilia, apicibus fastigatis; saepe ramosa vel torta; nonnulla forma inaequabilia ; 7-11 $\mu$ lata ; 22-30 $\mu$ longa. Cystidia raro inveniuntur. Sporae perdurantes azygosporae globosae, episporio leni atque crasso; cytoplasmate granoso vel vacuolato; 24-32 $\mu$ in diam., med. $27 \mu$. Hospes substrato fixus rhizoideis.

Hospes: Hemiptera, Aphidae. Therioaphis maculata (Buckton) in Medicagine sativa $\mathrm{L}$.

Conidia ovoid to elliptical with rounded ends, occasionally pyriform to irregular; uninucleate; length 17-23 $\mu$, average $20 \mu$; width $9-12 \mu$, average $11 \mu$. Secondary conidia like the primary but slightly smaller, each formed at the tip of a short germ tube growing terminally or laterally from primary conidium. Conidiophores branched, short; form a reddish cover over the entire host body. Hyphal bodies short, slender sections of hyphae with tapered ends, often branched or twisted; some irregular in shape; 7-11 $\mu$ thick, 22-30 $\mu$ long. Cystidia occur rarely on the host. Resting spores azygospores, spherical; epispore smooth, thick; cytoplasm granular to vacuolate; diameter 24-32 $\mu$, average $27 \mu$. Host attached to substratum by rhizoids. Host: Hemiptera, Aphidae. Therioaphis maculata (Buckton) on alfalfa, Medicago sativa L.

Habitat: India; Iraq; Israel; U. S. A.: California, Louisiana.

This fungus, with its ovoid conidia, bears a slight resemblance to the commonly occurring Empusa aphidis, although the differences in size of the conidia and resting spores plus the formation of slender, rather than spherical, hyphal bodies indicate that it is a different species. Culturally, the two species are quite different, for although $E$. exitialis is rather easily isolated and cultivated on a variety of artificial media, all attempts to isolate $E$. aphidis on similar media for comparative studies have failed.

\section{Entomophthora virulenta, n.sp.}

(Figs. 12-14)

Conidia globosa vel pyriformia, basi papillato, muro tenui, cytoplasmate granoso; longitudo (basi haud excepto) 20-32 $\mu, 26 \mu$; latitudo 16-28 $\mu$, med. $22 \mu$. Conidia secundaria primariis similia. Conidiophori non ramosi, coalescentes in tegumentum subbrunneum vel russeum super totum hospitis corpus. Corpora hyphalia segmenta brevia hypharum forma inaequabilia, saepe ramosa vel torta ; 8-12 $\mu$ lata, 30-60 $\mu$ (vel plura) longa. Cystidia raro inveniuntur. Sporae perdurantes plerumque azygosporae (sed nonnullae zygosporae inventae), globosae (sed nonnullae forma inaequabiles), episporio leni atque crasso, uno vel pluribus vacuolis (vel olei globulis) in cytoplasmate granoso; 15-31 $\mu$ (med. $22 \mu$ ) in diam.; neque chlamydosporae neque sporae interstitiales. Hospes substrato fixus rhizoideis.

Hospes: Hemiptera, Aphidae. Therioaphis maculata (Buckton) in Medicagine sativa $\mathrm{L}$.

Conidia spherical to pyriform, with papillate base, thin wall, granular cytoplasm; length (including base) 20-32 $\mu$, average $26 \mu$; width 16-28 $\mu$; average $22 \mu$. Secondary conidia like the primary. Conidiophores unbranched, forming a light-brown-to-reddish covering over the entire body of the host. Hyphal bodies short sections of hyphae of irregular shape, often branched 
or twisted; 8-12 $\mu$ thick, 30-60 $\mu$ (or more) long. Cystidia occur rarely. Resting spores generally azygospores (some zygospores noted), spherical (some irregular), with smooth, thick epispore and one to several large vacuoles or oil globules in granular cytoplasm; diameter $15-31 \mu$, average $22 \mu$; no chlamydospores or interstitial spores. Host attached to substratum by rhizoids.

Host: Hemiptera, Aphidae. Therioaphis maculata (Buckton) on alfalfa, Medicago sativa L.

Habitat: Israel; U. S. A.: California.

This fungus does not resemble closely any of the entomophthorous fungi previously described from aphids. It also differs morphologically, culturally, and pathogenically from the other newly described species which form spherical conidia. Like $E$. exitialis, the other fungus displaying marked pathogenicity for the spotted alfalfa aphid, the conidiophores of E. virulenta form a reddish covering over the entire host body.

\section{ACKNOWLEDGMENTS}

The authors wish to express appreciation to Dr. Douglass S. Parker for preparation of the Latin descriptions of the new species and to Dr. Irwin M. Newell for the photographs.

\section{LITERATURE CITED}

BUrGer, O. F. and A. F. SWAin.

1918. Observations on a fungus enemy of the walnut aphis in southern California. Jour. Econ. Ent. $11: 278-89$.

CoHN, F.

1855. Empusa muscae und die Krankheit der Stubenfliegen. Nova Acta K. Acad. Caes. Leop.-Carol. Germ. Nat. 25:301-60. (Cited by Thaxter)

\section{Costantin, J.}

1897. Sur une Entomophthorée nouvelle. Bull. Soc. Mycol. France. 13:38-43.

FitzPatrick, H. M.

1930. The lower fungi Phycomycetes. MeGraw-Hill Pub. Co. 331 pp.

Fresenius, G.

1856. Insekten-Ilze betreffend. Bot. Zeit. 14:882.

Fresenius, G.

1858. Über die Pilzgattung Entomophthora. Abhandl. Senkenberg. Gesell. 2:201-10.

HALL, I. M. and E. J. Dietrick.

1955. Fungi on spotted alfalfa aphid. Calif. Agric. 9(12):5, 16 .

HaLl, I. M. and P. H. DunN.

1957. Fungi on spotted alfalfa aphid. Calif. Agric. 11(2):5, 14.

HARRIS, M. R.

1948. A phycomycete parasitic on aphids. Phytopathol. 38(2):118-22.

Kevorian, A. G.

19:7. Studies in the Entomophthoraceae. I. Observations on the genus Conidiobolus. Jour. Agr. Puerto Rico $21: 191-200$.

MacLeod, D. M.

1956. Notes on the genus Empusa Cohn. Canad. Jour. Bot. 34:16-26.

Martin, G. W.

1925. Morphology of Conidiobolus villosus. Bot. Gaz. 80:311-8. 
Nowakowski, L.

1884. Entomophthoraceae. Przycrynek doznajomesci pasorzytnych grzybkow sprariajacyck pomor owadow. Pamietnik Akad. Umiejejnosei zu Krakau 8:153-83.

Petch, T. (Cited by Fitzpatrick.)

1932. A list of the entomogenous fungi of Great Britain. Trans. Brit. Mycol. Soc. $17: 170-8$.

Petch, T.

1937. Notes on entomogenous fungi. Trans. Brit. Mycol. Soc. 21:34-67.

Steinhaus, E. A.

1949. Principles of Insect Pathology. MeGraw-Hill Pub. Co. 757 pp.

THAXTER, R.

1888. The Entomophthoreae of the United States. Mem. Boston Soc. Nat. Hist. 4:133201. 



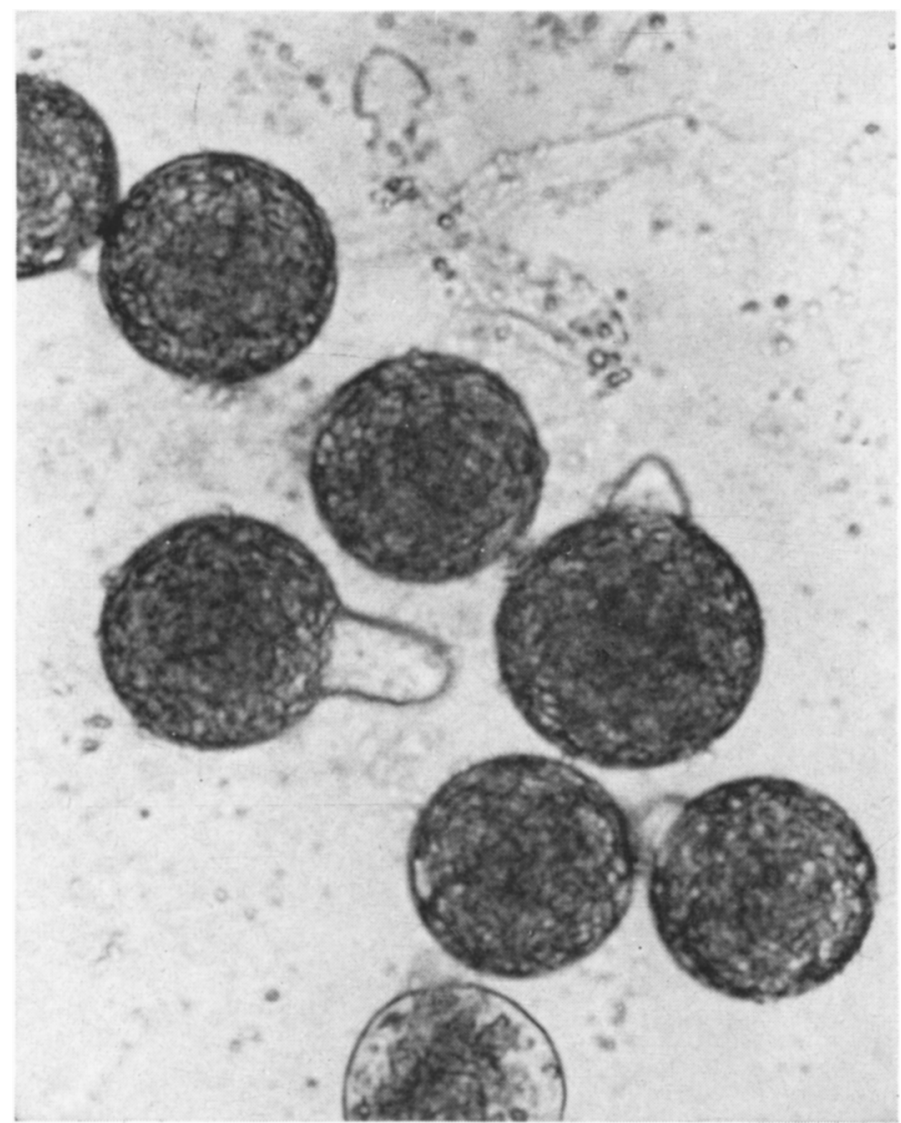

Fig. 1. Conidia of Entomophthora coronata (Cost.) Kevorkian. 


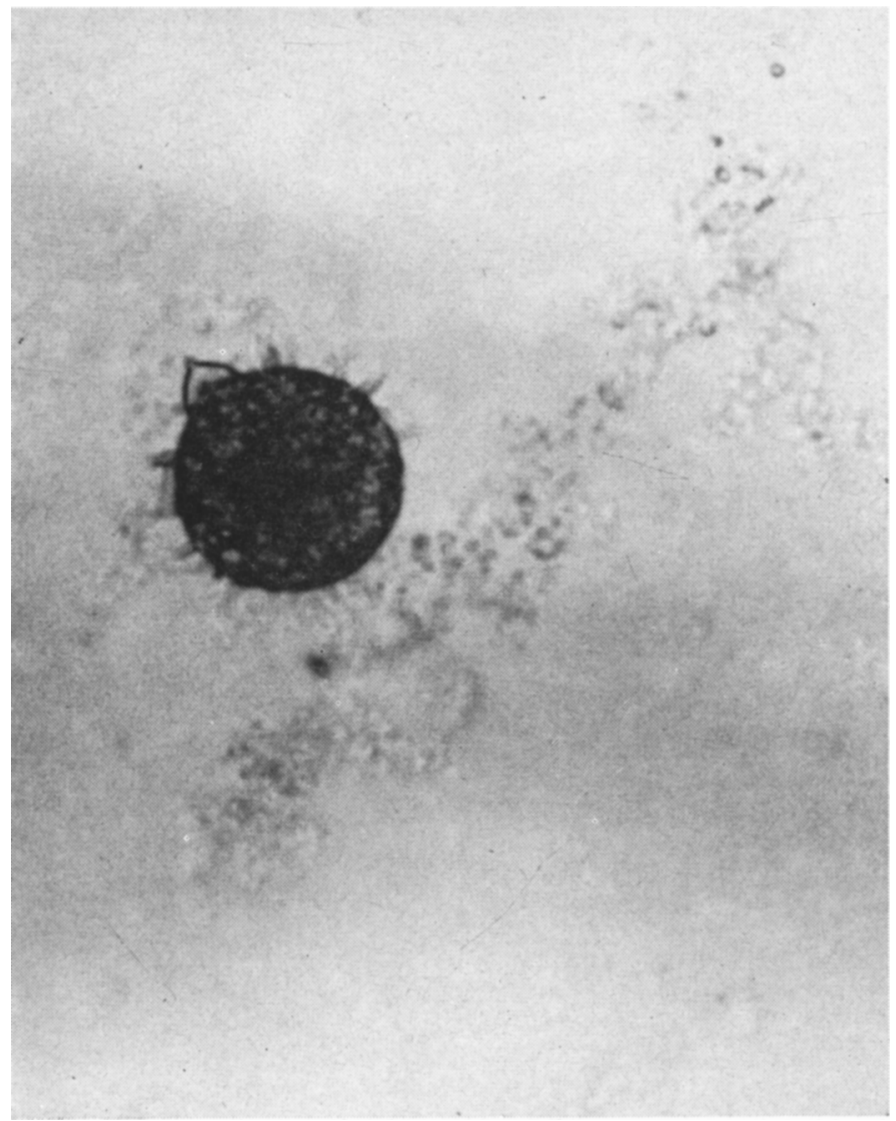

Fig. 2. Villose spore of E. coronata. 


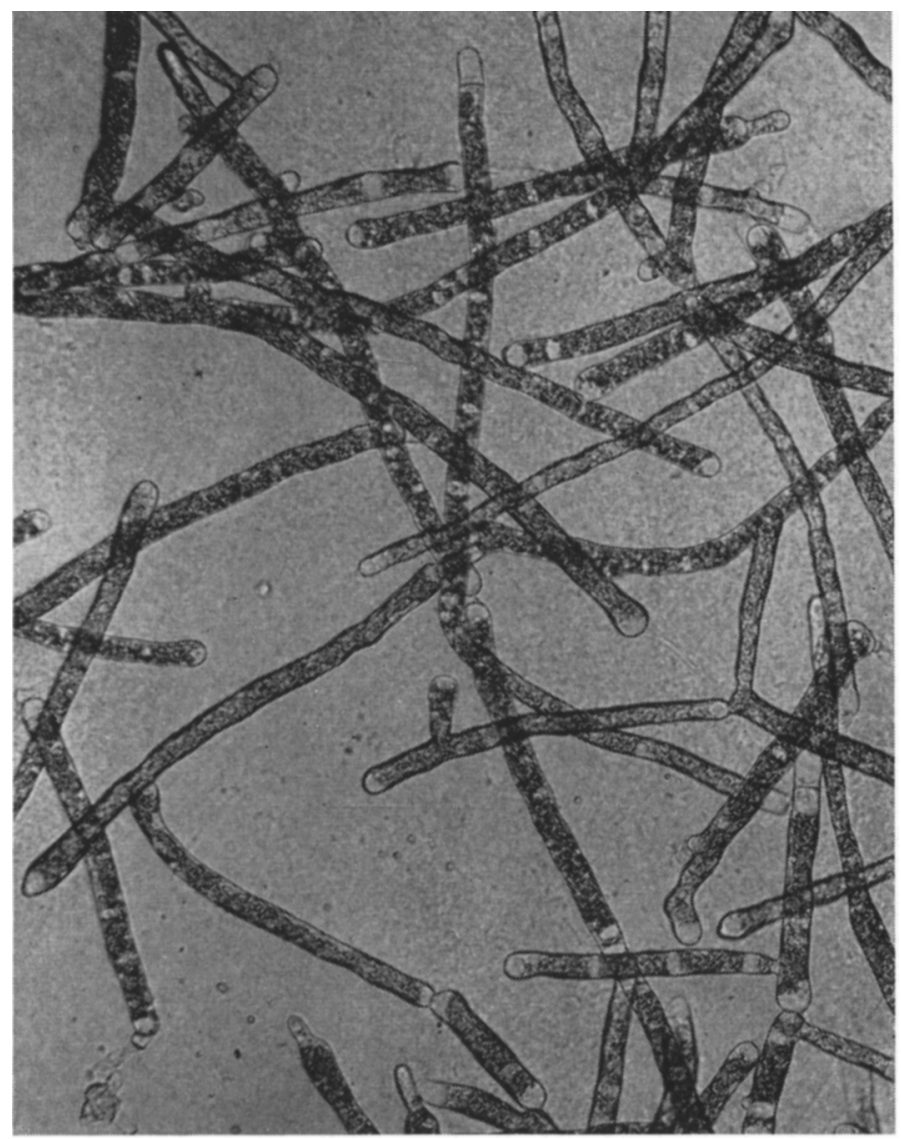

Fig. 3. Hyphal bodies of E. coronata grown on Sabouraud Dextrose Agar. 


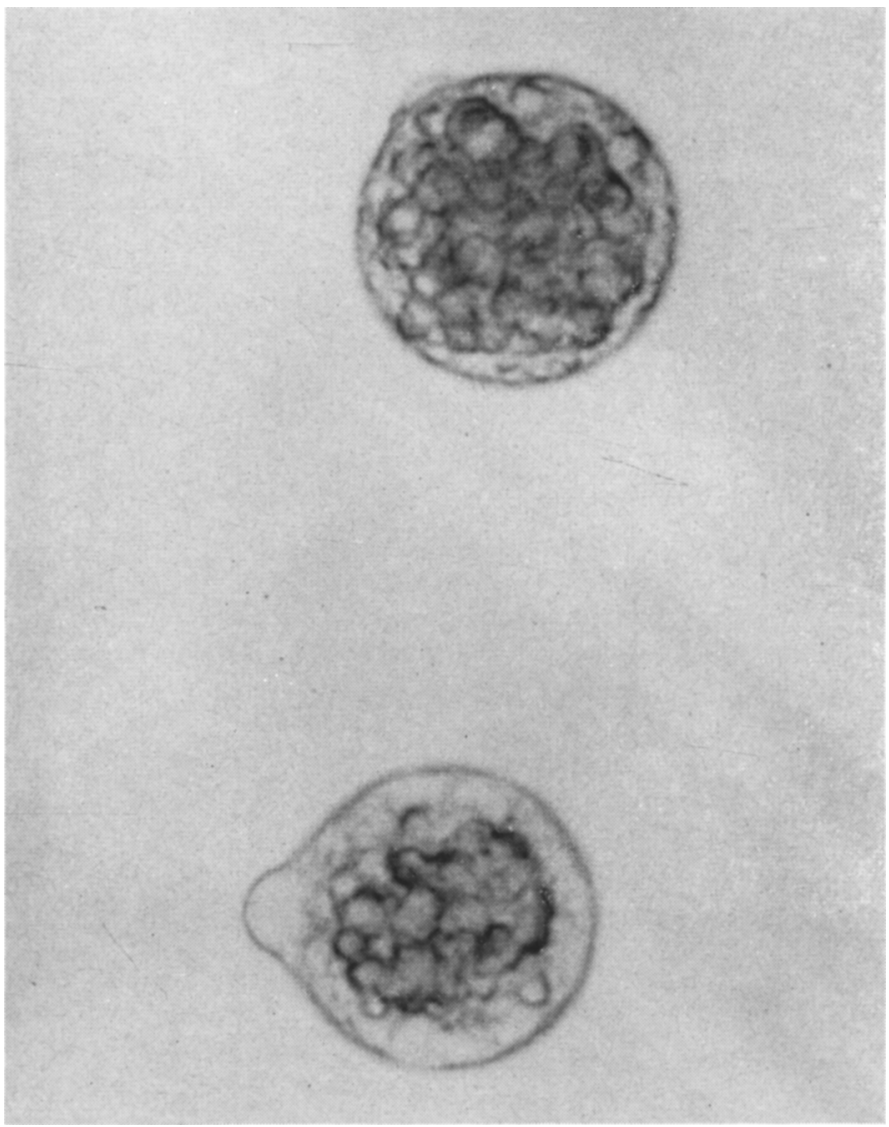

Fig. 4. Conidia of E. obscura n. sp. 


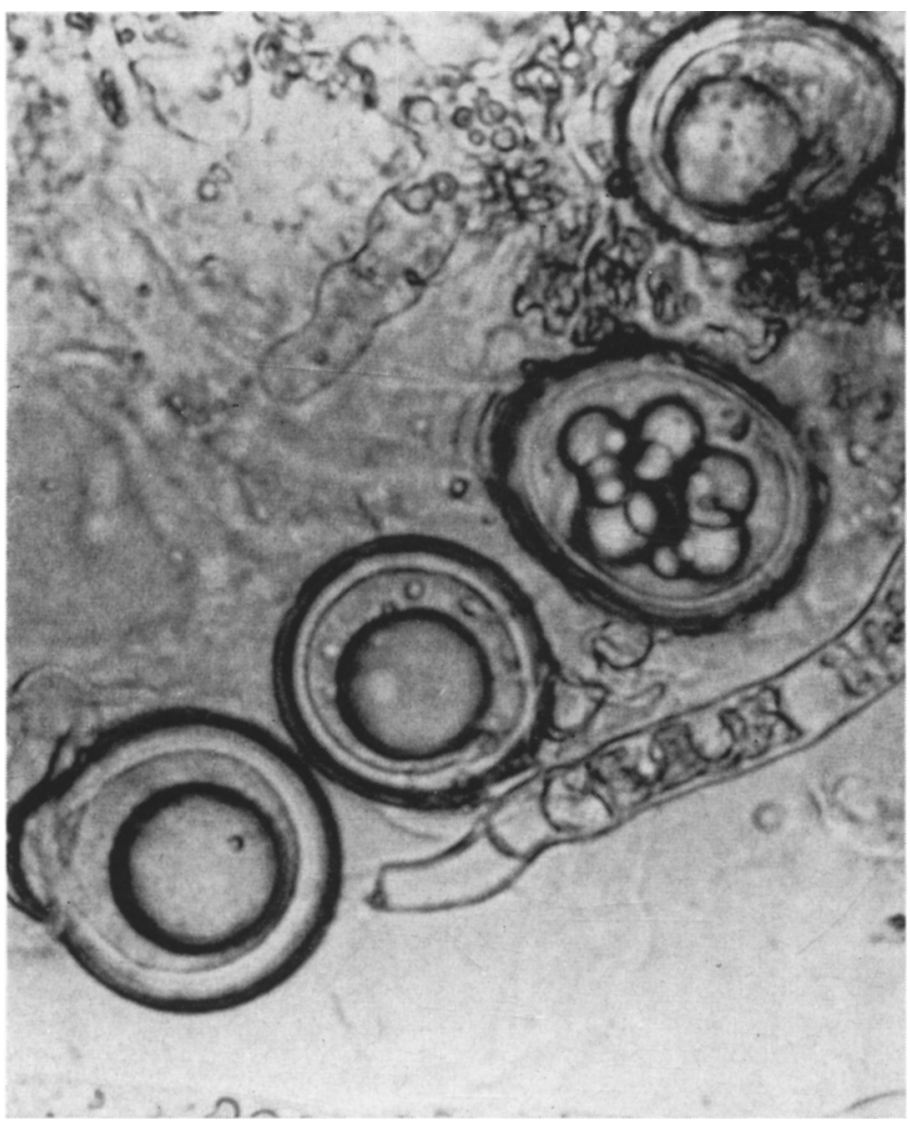

Fig. 5. Resting spores of E. obscura n. sp. 


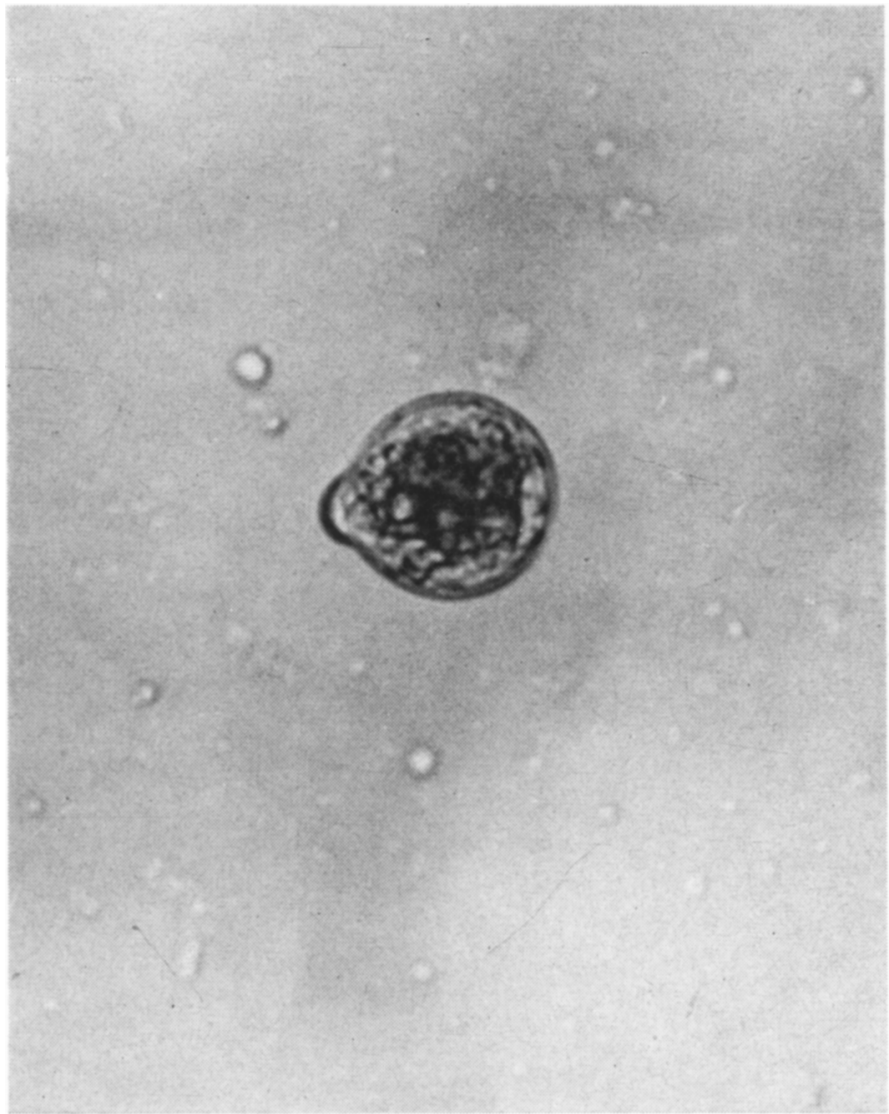

Fig. 6. Conidium of E. ignobilis, n. sp. 
[Vol. 27, No. 4

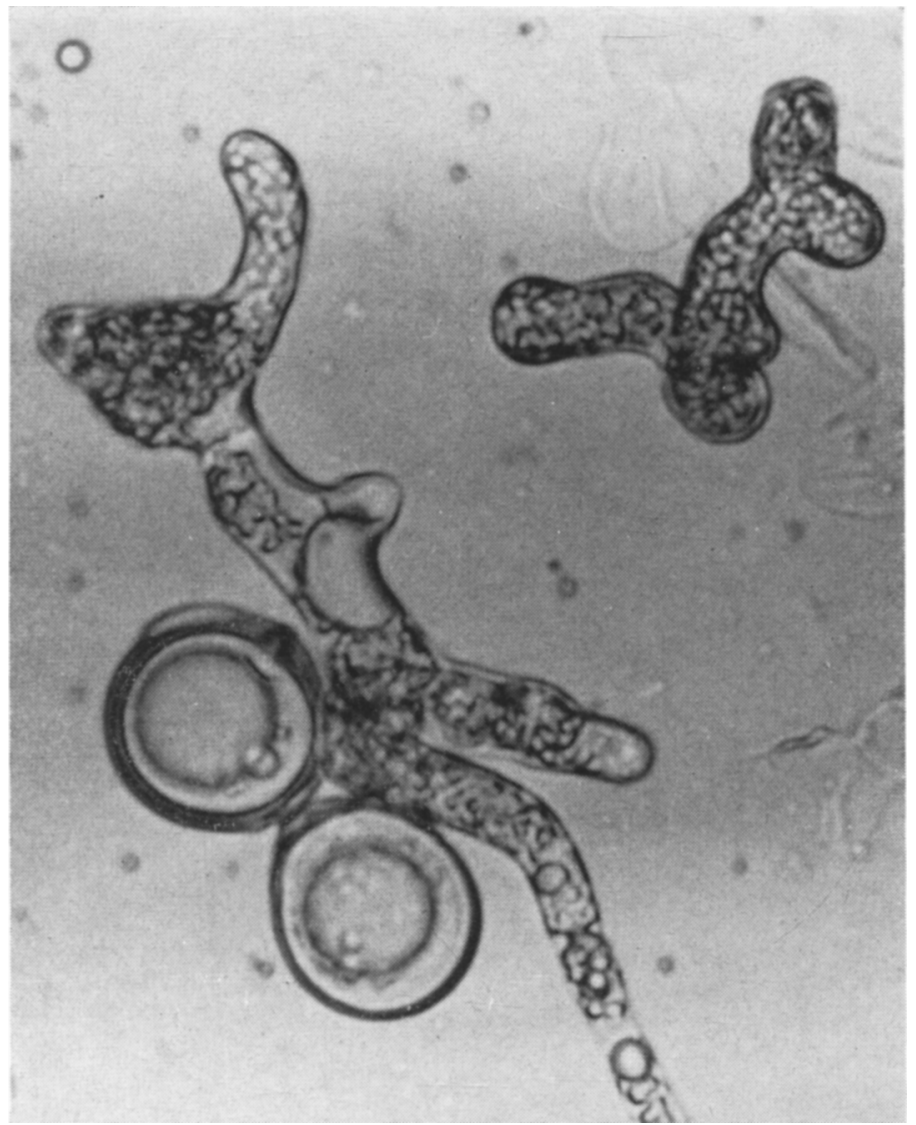

Fig. 7. Hyphal bodies and resting spores of E. ignobilis n. sp. grown on Sabouraud Dextrose Agar. 


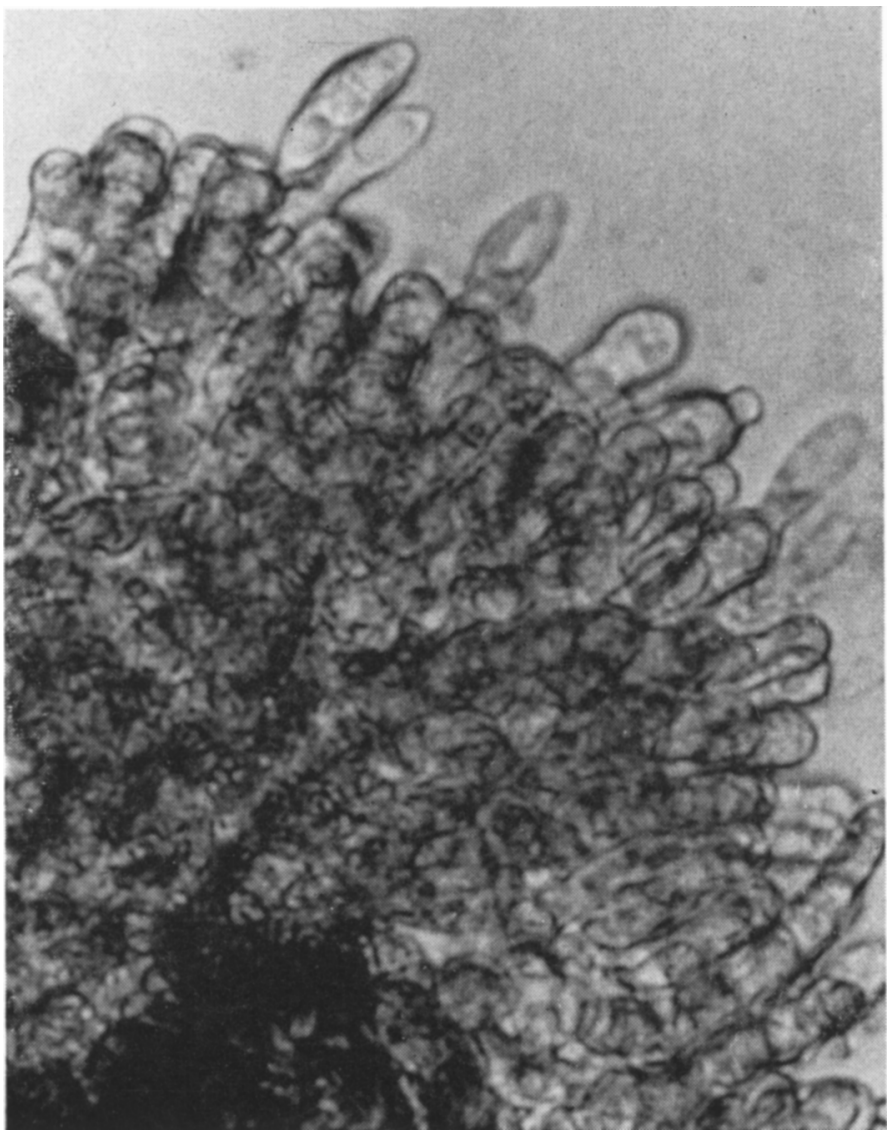

Fig. 8. Portion of spotted alfalfa aphid infected with $E$. exitialis n. sp. showing conidia and mass of conidiophores on surface of host. 


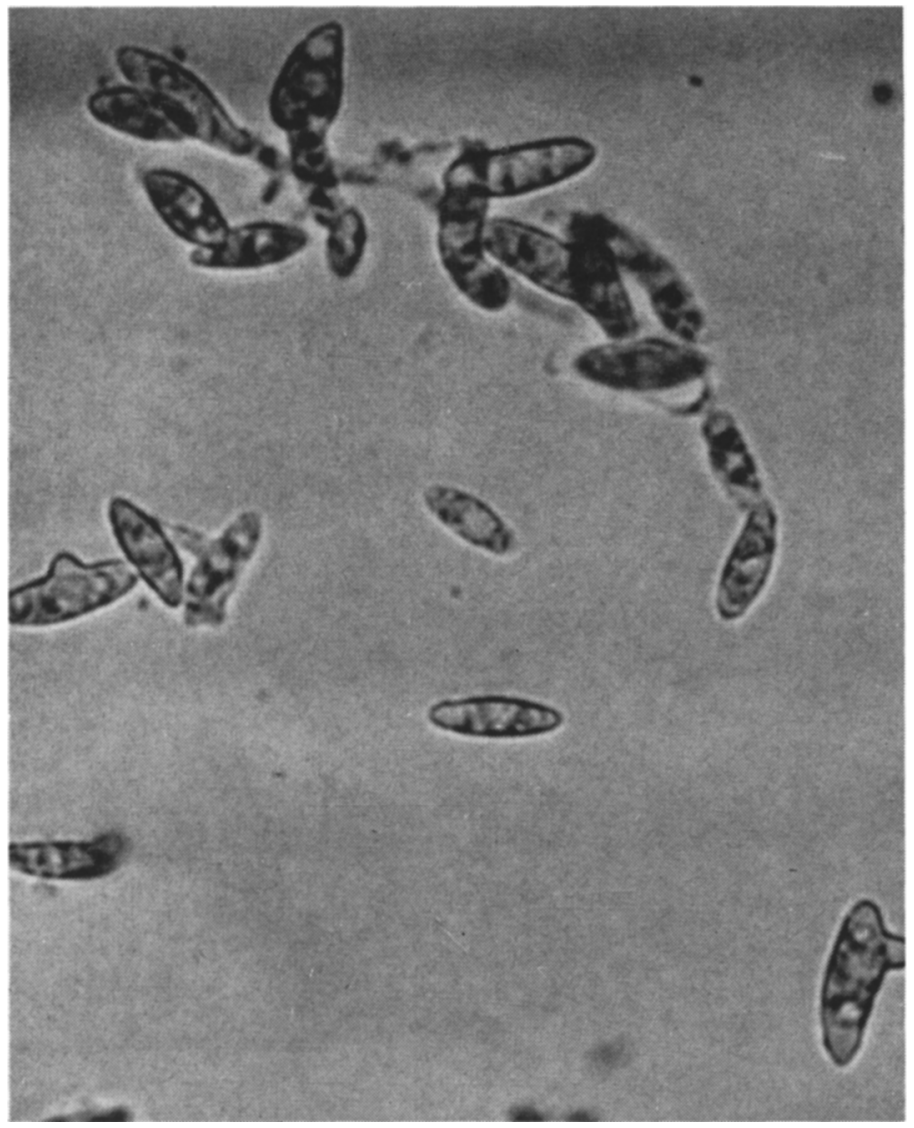

Fig. 9. Conidia of E. exitialis 1 . sp. 


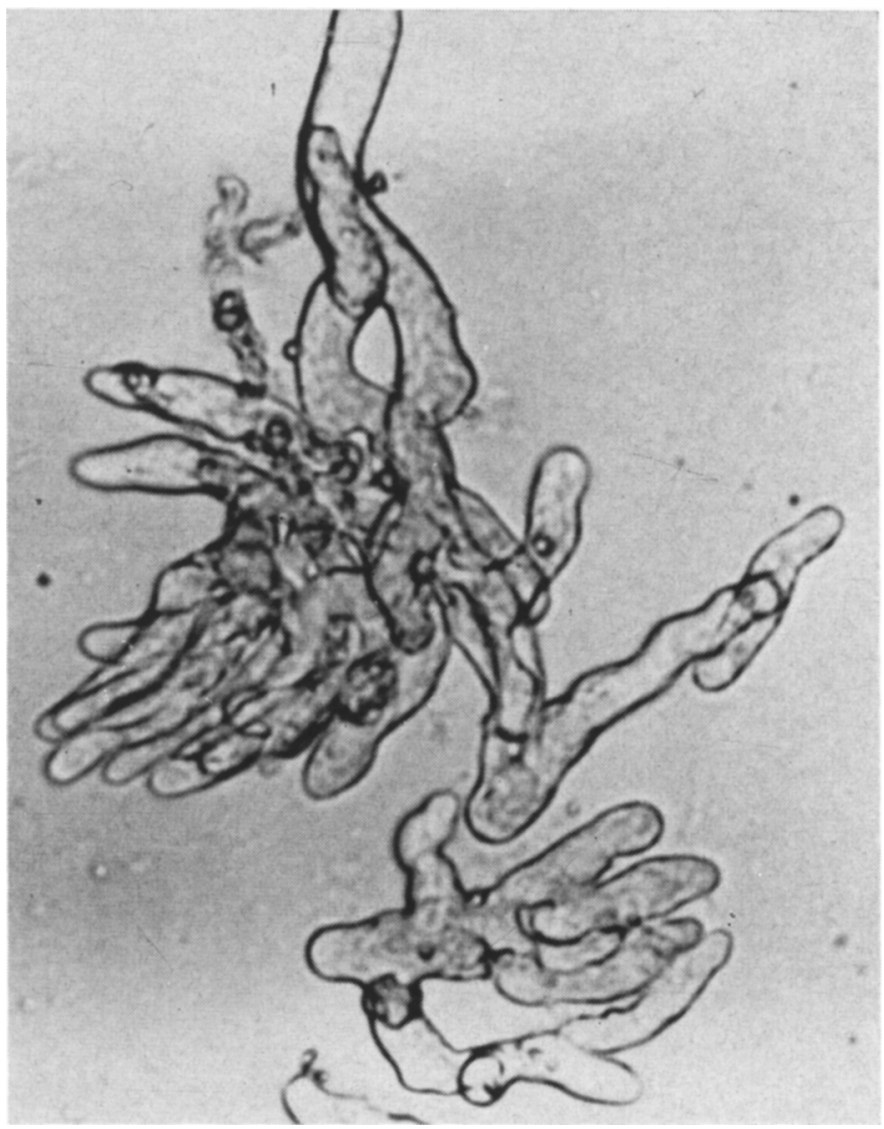

Fig. 10. Hyphal bodies of E. exitialis n. sp. 


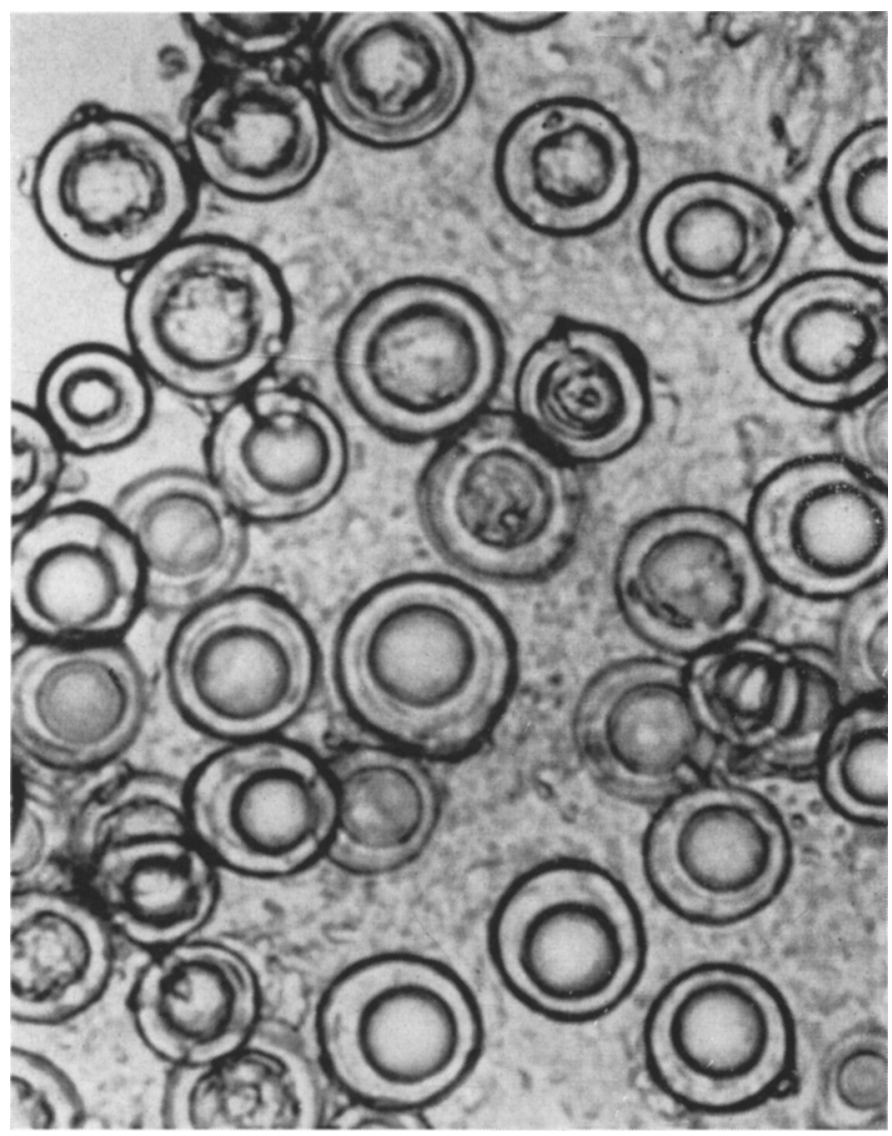

Fig. 11. Resting spores of E. exitialis n. sp. 


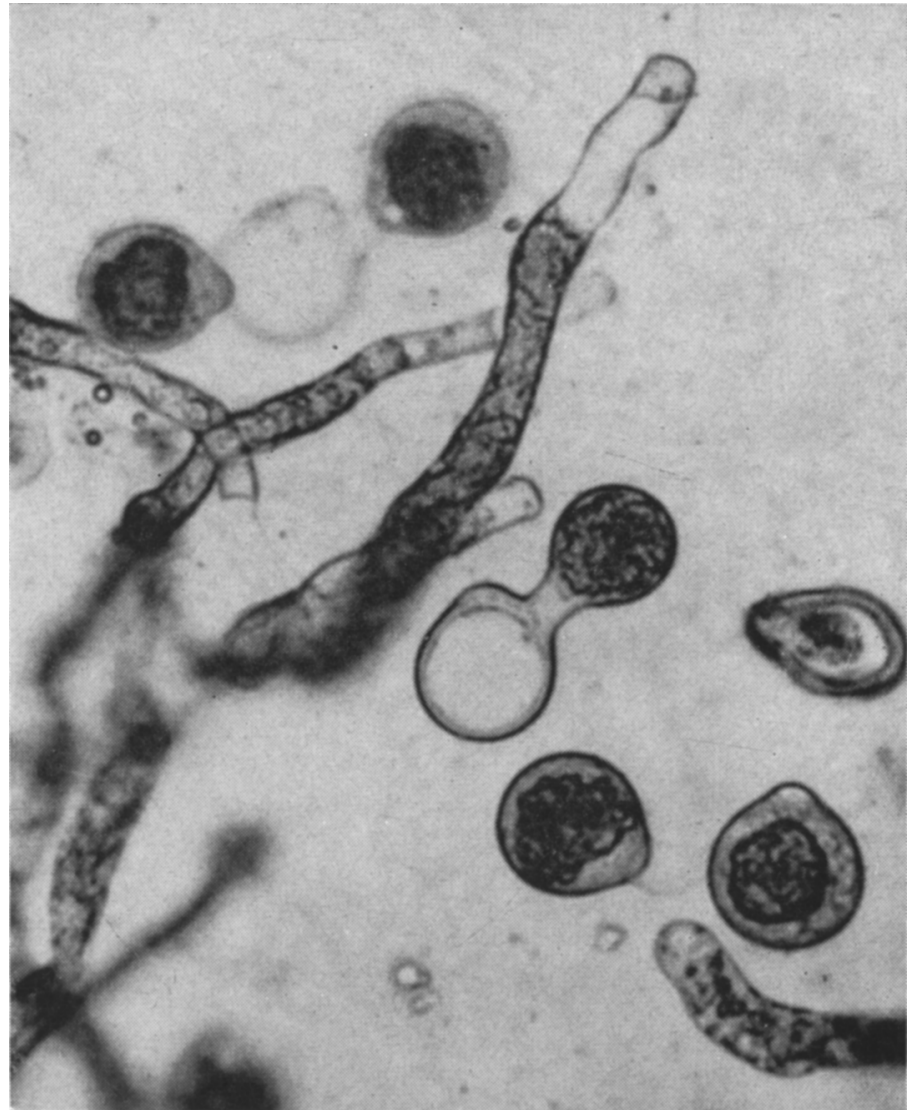

Fig. 12. Primary and secondary conidia of E. virulenta n. sp. 


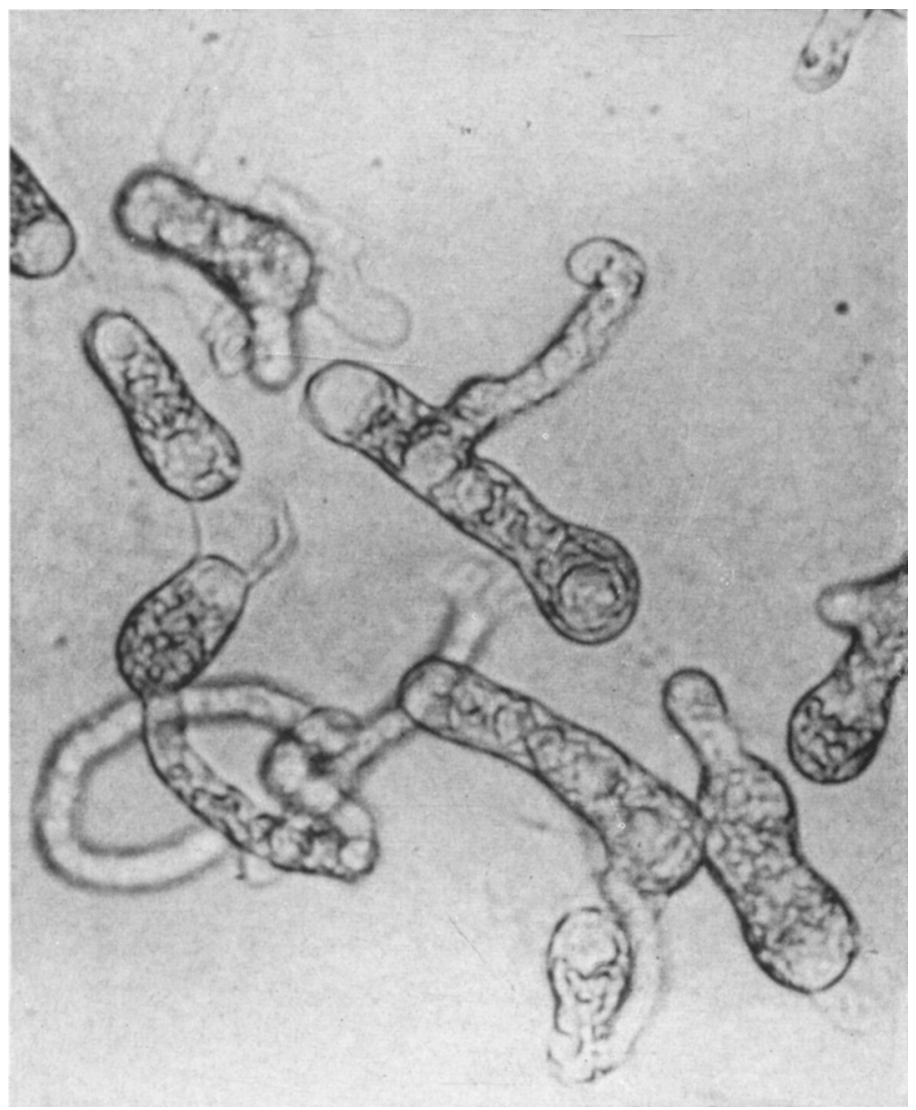

Fig. 13. Hyphal bodies of E. virulenta n. sp. grown on Sabouraud Dextrose Agar. 


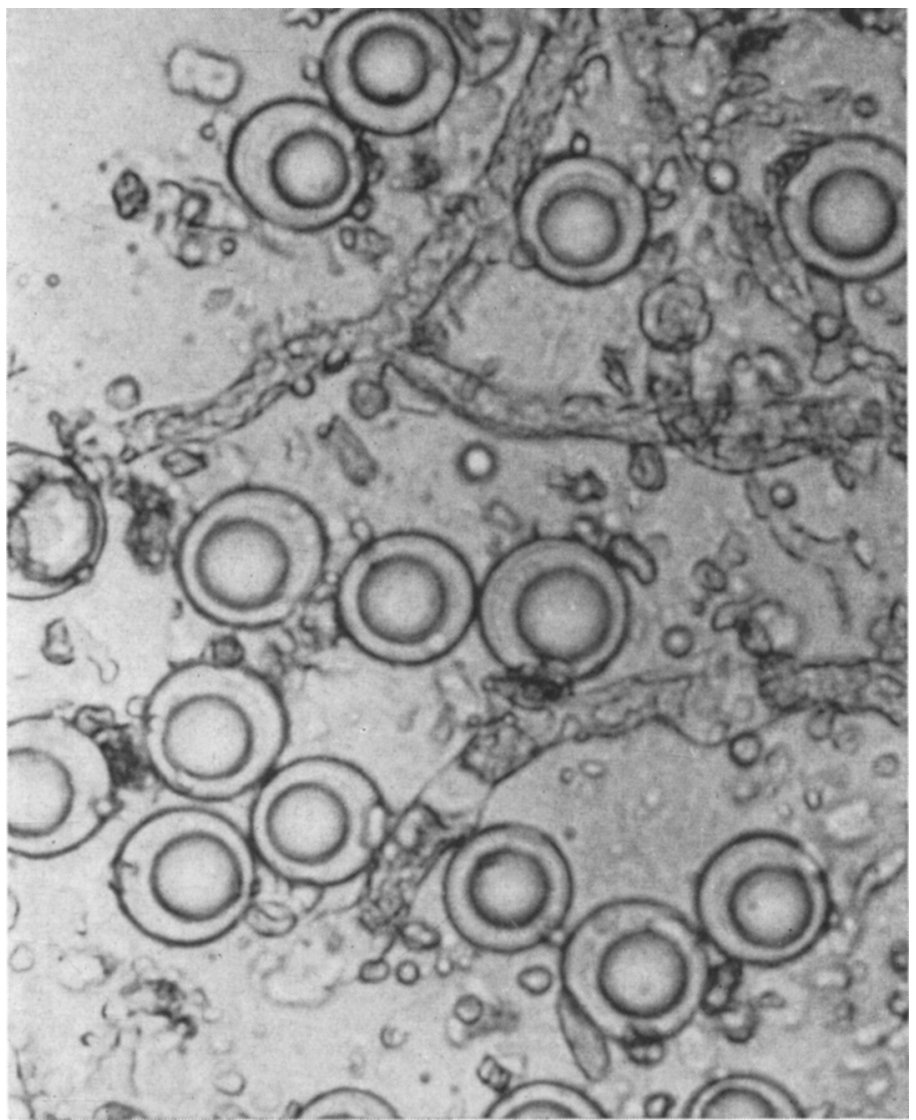

Fig. 14. Resting spores of E. virulenta n. sp. 

The journal Hilgardia is published at irregular intervals, in volumes of about 600 pages. The number of issues per volume varies.

Subscriptions are not sold. The periodical is sent as published only to libraries, or to institutions in foreign countries having publications to offer in exchange.

You may obtain a single copy of any issue free, as long as the supply lasts; please request by volume and issue number from:

$$
\begin{aligned}
& \text { Agricultural Publications } \\
& \text { Room 22, Giannini Hall } \\
& \text { University of California } \\
& \text { Berkeley 4, California }
\end{aligned}
$$

The limit to nonresidents of California is 10 separate issues on a single order. A list of the issues still available will be sent on request. 


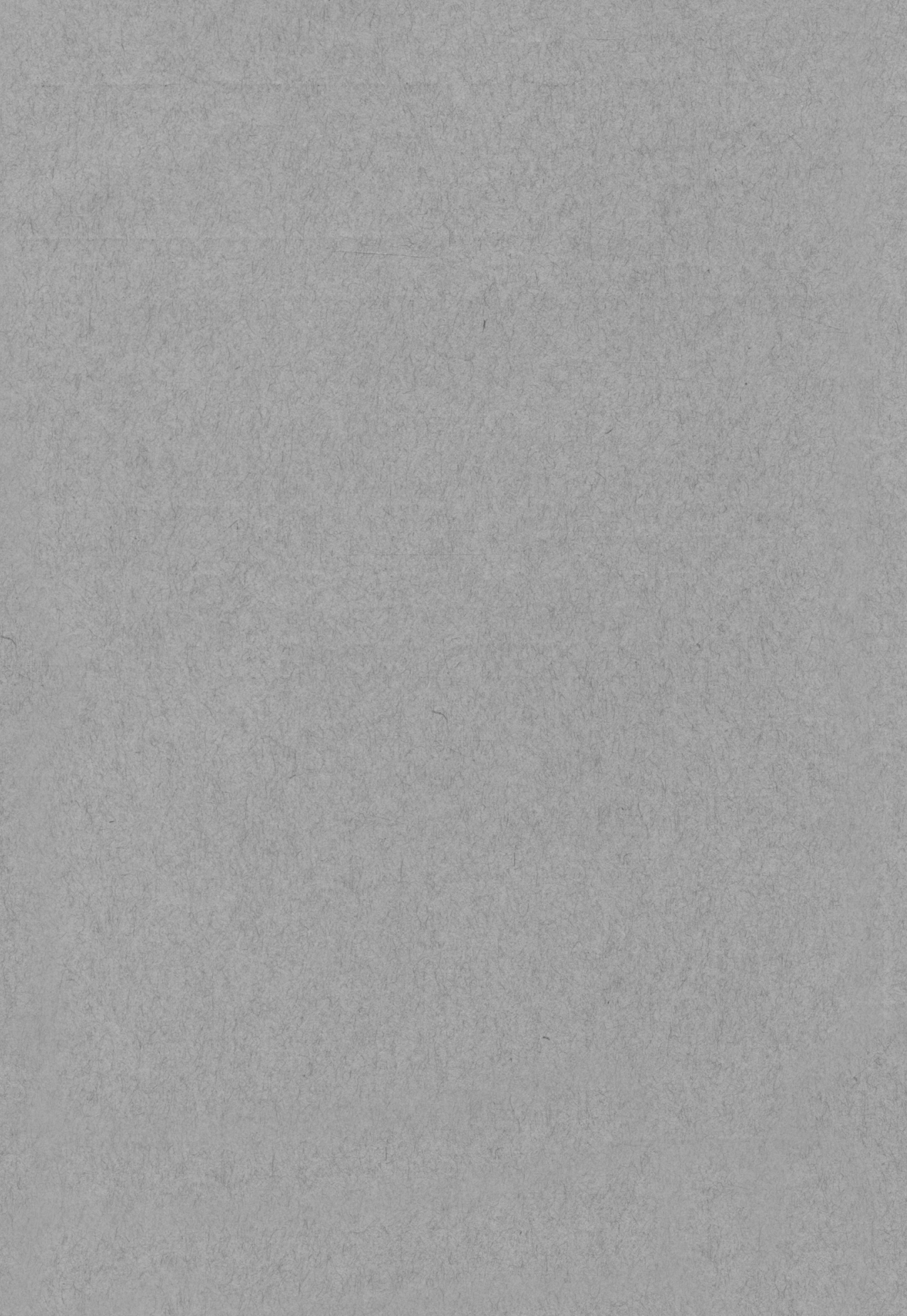

